\title{
Antidiarrheal and Antioxidant Activities of the Aerial Parts of Caralluma dalzielii N. E. Brown
}

\author{
Chinenye J. Ugwah-Oguejiofor ${ }^{1, *}$, Halilu E. Mshelia ${ }^{2,3}$, Junaidu Bello', Isah Inuwa' , Abdullahi Sulaiman'
}

Chinenye J. Ugwah-

Oguejiofor ${ }^{1, *}$, Halilu E. Mshelia ${ }^{2,3}$, Junaidu Bello', Isah Inuwa', Abdullahi Sulaiman ${ }^{1}$

'Department of Pharmacology and Toxicology, Faculty of Pharmaceutical Sciences Usmanu Danfodiyo University Sokoto, Sokoto, NIGERIA.

2Department of Faculty of Pharmacy, Cyprus International University, Nicosia, Mersin 10, TURKEY.

${ }^{3}$ Department of Pharmacognosy and Ethnopharmacy, Faculty of

Pharmaceutical Sciences, Usmanu

Danfodiyo University, P.M.B. 2346

Sokoto, NIGERIA.

Correspondence

Dr. Chinenye J. Ugwah-Oguejiofor

Department of Pharmacology and Toxicology, Faculty of Pharmaceutical Sciences Usmanu Danfodiyo University Sokoto, Sokoto, NIGERIA.

Email id: nenye789@yahoo.com

History

- Submission Date: 10-11-2021.

- Review completed: 07-12-2021

- Accepted Date: 21-12-2021.

DOI : 10.5530/pres.14.1.12

Article Available online

http://www.phcogres.com

\section{Copyright}

(C) 2022 Phcog.Net. This is an openaccess article distributed under the terms of the Creative Commons Attribution 4.0 International license.

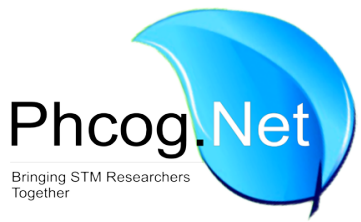

\begin{abstract}
Background: Caralluma dalzielii N.E. Brown is commonly referred to as "Karan massalanci" in the Northwest Nigeria where it is used in treating several ailments including pain, diarrhea and stomach issues. Objectives: This study was aimed to investigate the antidiarrheal and antioxidant activities of aqueous aerial parts extract of Caralluma dalzielii. Materials and Methods: The aqueous aerial parts extract of Caralluma dalzielii (CDE) (100, 200 and 400 $\mathrm{mg} / \mathrm{kg}$ ) was evaluated for antidiarrheal properties against gastrointestinal motility, castor oil-induced and prostaglandin- $E_{2}$ (PGE2) enteropooling models in Wistar rats. Its antioxidant properties were studied by determining the total phenolic content (TPC) using Folin-Ciocalteu reagent, its free radical scavenging activity using 1, 1-Diphenyl-2-Picrylhydrazyl (DPPH) and its ferric reducing antioxidant power (FRAP) assays using potassium ferrocyanide ferric chloride methods. Ascorbic acid was used as the reference. Spasmolytic effect was studied in isolated rabbit jejunum preparations in an organ bath experiment using acetylcholine (ACh). Results: CDE significantly $(p<0.05)$ reduced gastrointestinal transit of charcoal meal and the total number of diarrheal feces in the animals. The total phenolic content was determined to be $36.67 \pm 3.33 \mathrm{mg} \mathrm{GAE} / \mathrm{g}$. IC $\mathrm{C}_{50}$ value of $63.44 \mathrm{mg} / \mathrm{mL}$ was calculated in DPPH assay. The FRAP value was found to increase as the concentration of the extract increased. CDE inhibited acetylcholine-induced contraction of the rabbit jejunum in a concentration dependent manner with complete inhibition at $20.48 \mathrm{mg} / \mathrm{mL}$ of the extract. Conclusion: The extract of Caralluma dalzielii possesses antidiarrheal activities which may be related to its antimotility, antioxidant and antispasmodic properties.
\end{abstract}

Key words: Antioxidant, Antispasmodic, Caralluma dalzielii, Gastrointestinal motility, Rabbit jejunum.

\section{INTRODUCTION}

Diarrhoea can be described either as the passage of watery stool for not less than three times a day, ${ }^{[1]}$ or more objectively, as frequency in bowel movements such that a stool production volume or stool production weight of more than $200 \mathrm{~mL}$ or $200 \mathrm{~g}$ within $24 \mathrm{hr}$ is obtained. ${ }^{[2]}$ It has been rated as the second leading cause of death amongst children younger than five years of age. Global estimate of death due to diarrhoea is about 2.2 million people per year. ${ }^{[3]}$ Diarrhoea can be caused by a number of factors such as certain microorganisms, toxins, medications and many other agents that increase gastrointestinal tract (GIT) secretions. ${ }^{[4]}$

Over the years, human beings have relied on natural products to alleviate and treat their diseases. In the developing countries, over $80 \%$ of their healthcare needs are met by traditional sources. ${ }^{[5]}$ Medicinal plants have also been a source for modern medicines and examples of modern medicines developed from them abound. ${ }^{[6]}$ They are preferred over modern medicines because of their affordability, cost- effectiveness and fewer side effects. Search for newer drugs with less side effects and cheaper alternatives to modern medicine have continued in every area of health. Medicinal plants that have been employed in treating diarrhoea which have been scientifically validated are many and more are still being evaluated..$^{[7-10]}$

Caralluma dalzielii (Family: Asclepiadaceae) popularly referred to as Mosque stalk is a shrub that resembles cactus plant. C. dalzielii is widely distributed in the Sahel region of Africa where its height ranges from 0.5 to $1 \mathrm{~m}$. In North-West Nigeria, the plant is used in treating several ailments including diarrhoea, stomach upset, convulsion and infertility. ${ }^{[11]}$ Snake and scorpion bites, rheumatoid arthritis, diabetes, emesis, leprosy, and severe pains in the epigastrium are other medicinal uses of the plant. ${ }^{[12,13]}$ The aim of this study was to evaluate the antidiarrheal and antioxidant activities of the aqueous extract of Caralluma dalzielii. 


\section{MATERIALS AND METHODS}

\section{Preparation of plant extract}

The aerial parts of the Caralluma dalzielii were collected from Tureta town, Sokoto State, North-West Nigeria. Identification and authentication of the plant were carried out by Mr. Musa Magaji, a taxonomist at the Department of Pharmacognosy and Ethnopharmacy, Usmanu Danfodiyo University Sokoto (UDUS). A voucher specimen (PCG/UDUS/ASCL/0003) was stored. The plant material was air-dried at room temperature for 4 weeks and pulverized with mortar and pestle. Soxhlet extraction method was employed in extracting $285 \mathrm{~g}$ of the powdered plant material in distilled water. The extract realized was dried over water bath at $50^{\circ} \mathrm{C}$ and the percentage yield was calculated.

\section{Experimental animals}

Healthy male Wistar rats (Rattus norvergicus) (150-200 g) and New Zealand white rabbits $(1.25-1.5 \mathrm{~kg})$ were obtained from the animal facility center of Ahmadu Bello University (ABU) Zaria. The animals were kept under standard environmental condition of $25^{\circ} \mathrm{C}$ and $12 \mathrm{hr}$ light and dark cycle. The animals had free access to feed and water for 14 days before the study commenced for them to acclimatize to the laboratory conditions. The study was approved by the Animal research ethics committee of Department of Pharmacology and Toxicology Usmanu Danfodiyo University, Sokoto (PTAC/Cd/CAE/23-19).

\section{Phytochemical screening}

Qualitative tests for the presence of saponins, terpenoids, tannins, flavonoids, steroids, glycosides, anthraquinones, alkaloids and fixed oils were carried out. ${ }^{[14]}$

\section{Antioxidant activity determination \\ Determination of total phenolic content (TPC)}

The TPC was determined using Folin-Ciocalteu method. ${ }^{[15]}$ The FolinCiocalteu reagent was added to $20 \mathrm{mg}$ of the extract in $20 \mathrm{ml}$ of $95 \%$ methanol and allowed incubate for $5 \mathrm{~min}$. After that, $\mathrm{Na}_{2} \mathrm{CO}_{3}$ was mixed with it and incubated at room temperature for $2 \mathrm{hr}$. The absorbance was then measured at $765 \mathrm{~nm}$ on a UV spectrophotometer. A calibration curve prepared with gallic acid as reference standard was used to calculate the TPC. The results were expressed as Gallic acid equivalent (mg GAE/g).

\section{Determination of free radical scavenging activity (FRSA)} using 1, 1-Diphenyl-2-Picrylhydrazyl (DPPH) Assay

Previously described method, ${ }^{[16]}$ was used to estimate the DPPH FRSA of the extract. Samples of the extract and the reference antioxidant (ascorbic acid) were prepared separately in varying concentrations of $0.01-0.2 \mathrm{mg} / \mathrm{mL}$ in methanol. A concentration of $100 \mu \mathrm{M}$ of DPPH was prepared and $2 \mathrm{~mL}$ of it was mixed with $2 \mathrm{~mL}$ of methanol and left in the dark for $30 \mathrm{~min}$. In the same way, $2 \mathrm{~mL}$ of the prepared DPPH was also mixed thoroughly with the different concentrations of the extract and ascorbic acid and kept in the dark for the same period of time. After that, the absorbance of mixtures were measured at $517 \mathrm{~nm}$. The percentage radical scavenging activities were calculated thus:

$\%$ Radical scavenging activities $=\left(\mathrm{A}_{\mathrm{o}}-\mathrm{A}_{\mathrm{t}} / \mathrm{A}_{\mathrm{o}}\right) \times 100$

Where $A_{o}=$ absorbance of DPPH in methanol; $A_{t}=$ absorbance of the extract or reference sample. The $\mathrm{IC}_{50}$ (effective concentration of the extract required to inhibit DDPH radical formation by $50 \%$ ) values were calculated by obtaining the regression equation from plotting the percentage radical scavenging activities against concentrations.

\section{Determination of ferric reducing antioxidant power assay (FRAP)}

The FRAP of the extract was estimated using potassium ferrocyanide ferric chloride method. ${ }^{[17]} \mathrm{A}$ volume of $2.5 \mathrm{~mL}$ of various concentrations of the extract was mixed with $2.5 \mathrm{~mL}$ of potassium ferrocyanide and incubated at $50^{\circ} \mathrm{C}$ for $20 \mathrm{~min}$. After that, $2.5 \mathrm{~mL}$ of $10 \%$ trichloroacetic acid was then added to the mixture and centrifuged at $3000 \mathrm{rpm}$ for $20 \mathrm{~min}$. Then, $2.5 \mathrm{~mL}$ of the supernatant was mixed with $0.5 \mathrm{~mL}$ of freshly prepared $0.1 \%$ ferric chloride. Various concentrations of the standard (ascorbic acid), was prepared using the same procedure. Their absorbance were measured at $700 \mathrm{~nm}$. The result was expressed in $\mathrm{mg}$ of ascorbic acid (AAE)/mL of the extract.

\section{Antidiarrheal activity evaluation \\ Gastrointestinal motility test}

The animals were fasted for $18 \mathrm{hr}$ and divided into five groups $(n=5)$. Groups I-III received oral doses of 100,200 and $400 \mathrm{mg} / \mathrm{kg}$ of the extract. Group IV received loperamide $(2.5 \mathrm{mg} / \mathrm{kg}$ ) (positive control) while group $\mathrm{V}$ received distilled water $(5 \mathrm{~mL} / \mathrm{kg})$ (negative control). A $1 \mathrm{~mL}$ of charcoal meal which consisted of $10 \%$ charcoal suspension in $5 \%$ gum acacia, was administered orally to the rats $30 \mathrm{~min}$ after treatment. After an hour, the animals were sacrificed and the distance moved by the charcoal meal from the pylorus towards the caecum was measured. The percentage of the distance moved by charcoal meal to the total length of the intestine (TLI) was calculated. ${ }^{[18]}$ Peristalsis index and percentage inhibition of mobility were calculated as

Peristalsis index $=$ Distance travelled by charcoal meal/ Length of intestine $\times 100$

$\%$ inhibition of mobility $=($ TLI - Distance travelled by test group $) /$ TLI $\times 100$.

\section{Castor oil-induced diarrhoea test}

Healthy Wistar rats were fasted for $18 \mathrm{hr}$ and allocated into five groups $(n=5)$. Groups I-III were the extract groups and were treated with 100 , 200 and $400 \mathrm{mg} / \mathrm{kg}$ p.o of the extract. Group IV was the reference drug group treated with loperamide $2.5 \mathrm{mg} / \mathrm{kg}$, p.o. while group $\mathrm{V}$ received the vehicle ( $5 \mathrm{~mL} / \mathrm{kg}$ p.o) and represented the control group. After $1 \mathrm{hr}$ of extract, drug or vehicle pre-treatment, all rats were given $1 \mathrm{~mL}$ of castor oil orally to induce diarrhea. All the animals were kept in separate metallic cages with a plain absorbent sheet of paper at the floor and were observed every hour for $4 \mathrm{hr}$. The total number of diarrhoea feces were noted and the percentage diarrhoea inhibition calculated. ${ }^{[19]}$

$\%$ diarrhoea inhibition $=\left(\mathrm{T}_{\mathrm{o}}-\mathrm{T}_{1} / \mathrm{T}_{\mathrm{o}}\right) \times 100$

$\mathrm{T}_{\mathrm{o}}=$ number of wet feces in vehicle control group

$\mathrm{T}_{1}=$ number of wet feces in test group

\section{Prostaglandin- $E_{2}$ (PGE2) enteropooling test}

Twenty-five healthy rats were fasted for $18 \mathrm{hr}$ and divided into five groups $(n=5)$. Groups I-III were the extract groups and received 100, 200 and $400 \mathrm{mg} / \mathrm{kg}$ p.o. respectively of the aqueous extract of Caralluma dalzielii. Group IV represented the standard drug, loperamide $(2.5 \mathrm{mg} /$ $\mathrm{kg}$ ) while the group $\mathrm{V}$ was the vehicle control group that received $5 \mathrm{~mL} /$ $\mathrm{kg}$ of distilled water. After $1 \mathrm{hr}$ of treatment, $100 \mu \mathrm{g} / \mathrm{kg}$ of PGE2 was administered orally to all the animals to induce enteropooling. After a period of $30 \mathrm{~min}$, all animals were sacrificed and the whole intestines dissected. The intestinal contents were collected and the total volume measured. ${ }^{[20]}$ 


\section{Determination of spasmolytic activities}

Isolated rabbit jejunum experiment

The rabbit was decapitated and its jejunum dissected out and placed in tyrode solution with a controlled temperature of $37^{\circ} \mathrm{C}$ and aerated. About $2-3 \mathrm{~cm}$ of the jejunum was cut out and tied to the isotonic transducer connected with a data acquisition interface (PowerLab) and computer screen for displaying isometric contractions. ${ }^{[21]}$ Isometric concentrations were recorded under a resting tension. The set up was allowed an equilibration period of $30 \mathrm{~min}$. Dose-response relationships were established using standard acetylcholine (Ach) at 1, 2, 4, 8 and $16 \mu \mathrm{g} / \mathrm{mL}$. To assess the inhibitory effect of the extract on Ach, $8 \mu \mathrm{g} / \mathrm{mL}$ of Ach which gave the highest response was used. The dose-responses of extract at $1.28,2.56,5.12,10.24$ and $20.48 \mathrm{mg} / \mathrm{mL}$ were established against $8 \mu \mathrm{g} / \mathrm{mL}$ of Ach. The response time for each treatment was for a minimum of 2 min before three times washing with tyrode solution.

\section{RESULTS}

\section{Phytochemical analysis}

The extract was found to contain saponins, terpenoids, tannins, flavonoids, steroids, glycosides, alkaloids and fixed oils.

\section{Antioxidant screening}

CDE had TPC of $36.67 \pm 3.33 \mathrm{mg} \mathrm{GAE} / \mathrm{g}$. The in vitro DPPH free radical scavenging activity revealed that the extract had antioxidant activity (Figure 1). This was seen from the $\mathrm{IC}_{50}$ obtained from the regression coefficient $\left(\mathrm{R}^{2}\right)$. The extract demonstrated antioxidant activity by scavenging DPPH radical with an $\mathrm{IC}_{50}$ of $63.44 \mathrm{mg} / \mathrm{mL}$ calculated from y $=0.03058 \mathrm{x}+61.91$ (where $\mathrm{x}=50$ ) and $R 2$ of 0.003273 as compared with ascorbic acid with an $\mathrm{IC}_{50}$ of $80.47 \mathrm{mg} / \mathrm{mL}$ calculated from $\mathrm{y}=1.038 \mathrm{x}+$ 28.57 (where $\mathrm{x}=50$ ) with $R 2$ of 0.03015 . The results revealed that CDE and ascorbic acid demonstrated free radical scavenging activity but the activity demonstrated by CDE was higher than that of the ascorbic acid. In the FRAP determination, the reducing ability of the extract expressed as ascorbic acid equivalence was found to be concentration dependent (Figure 2).

\section{Antidiarrheal evaluation}

In the gastrointestinal motility test, administration of CDE at all dose levels significantly $(p<0.05)$ reduced the speed of transit of charcoal meal towards the caecum. The inhibition of gastrointestinal motility was dose dependent (Table 1).

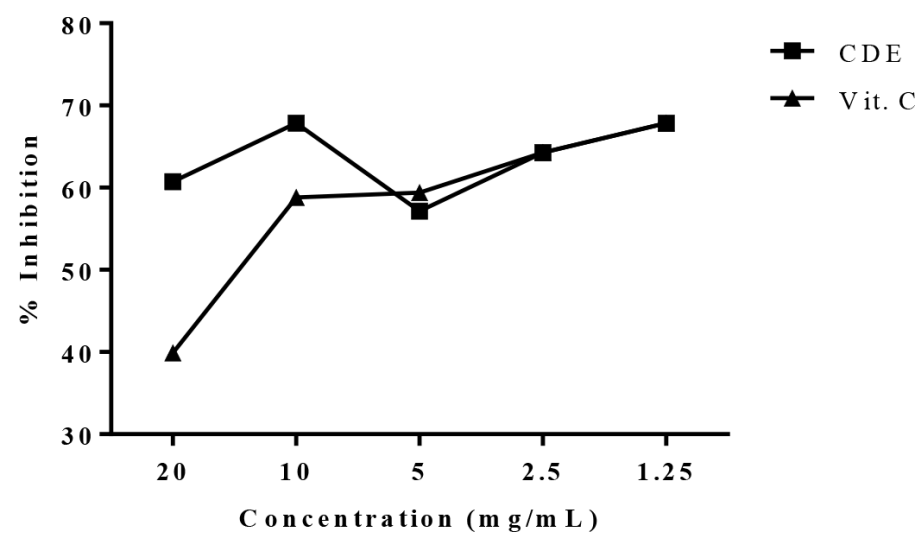

Figure 1: DPPH radical scavenging of Caralluma dalzielii. CDE: Extract of Caralluma dalzielii; Vit. C: Ascorbic acid

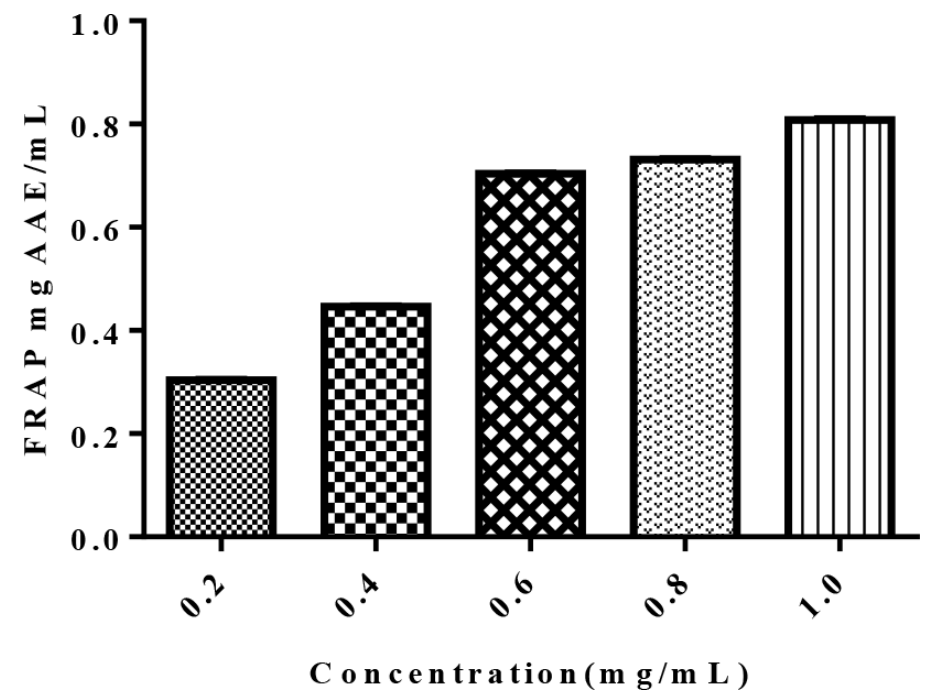

Figure 2: Ferric Reducing Antioxidant Power (FRAP) of Caralluma dalzielii. AAE: Ascorbic acid equivalent.

Table 1: Effect of aqueous extract of Caralluma dalzielii on the gastrointestinal transit of charcoal meal in rats.

\begin{tabular}{|c|c|c|c|c|c|}
\hline 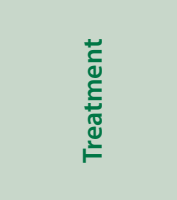 & 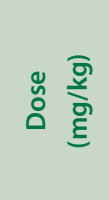 & 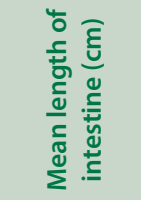 & 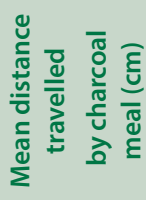 & 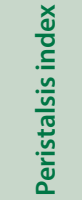 & 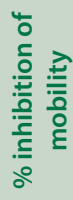 \\
\hline$C D E$ & 100 & $89.90 \pm 0.51$ & $77.59 \pm 1.74$ & 86.3 & 13.69 \\
\hline$C D E$ & 200 & $88.46 \pm 0.92$ & $70.46 \pm 2.65$ & $79.65^{*}$ & 20.35 \\
\hline$C D E$ & 400 & $89.14 \pm 0.84$ & $64.88 \pm 1.02$ & $72.78^{*}$ & 27.22 \\
\hline Loperamide & 2.5 & $88.96 \pm 1.54$ & $59.36 \pm 0.88$ & $65.98^{*}$ & 33.27 \\
\hline Distilled water & $5 \mathrm{~mL} / \mathrm{kg}$ & $90.38 \pm 0.50$ & $79.46 \pm 2.73$ & 87.92 & 12.08 \\
\hline
\end{tabular}

$\mathrm{CDE}=$ Caralluma dalzielii extract; values are presented as mean $\pm \mathrm{SEM}(\mathrm{n}=5)$; ${ }^{*} p<0.05$ significant when compared to distilled water control group

At $400 \mathrm{mg} / \mathrm{kg}$, the extract in castor oil-induced diarrhoea produced significant $(p<0.05)$ number of diarrhoea feces in the first and second hours. However, by the third and fourth hours, diarrhoea feces were produced significantly $(p<0.05)$ at all dose levels when compared to the control (Table 2). The extract inhibited the mean number of diarrheal feces in a dose dependent manner. The inhibition at $400 \mathrm{mg} / \mathrm{kg}$ was significantly $(p<0.05)$ lower than that of the control group (Figure 3$)$.

The extract failed to inhibit the intestinal content in the enteropooling test. Instead, it dose dependently increase the intestinal content. At $400 \mathrm{mg} / \mathrm{kg}$ of the extract, the intestinal content was significantly $(p<0.05)$ higher than that of the control group (Table 3 ).

\section{Effect of Caralluma dalzielii on isolated rabbit jejunum}

Acetylcholine at various concentrations of $1,2,4,8$ and $16 \mu \mathrm{g} / \mathrm{mL}$ caused a concentration-dependent contraction of the rabbit jejunum, while the extract $(1.28-20.48 \mathrm{mg} / \mathrm{mL})$ produced a dose dependent inhibition of the spontaneous contraction of the jejunum. At $20.48 \mathrm{mg} / \mathrm{mL}$ of the extract, the extract completely abolished the contraction produced by $8 \mu \mathrm{g} / \mathrm{mL}$ of Ach (Figure 4). 
Table 2: Effect of aqueous extract of Caralluma dalzielii on castor oil-induced induced diarrhoea feces per hour.

\begin{tabular}{|c|c|c|c|c|c|c|}
\hline Treatment & $\begin{array}{c}\text { Dose } \\
(\mathrm{mg} / \mathrm{kg})\end{array}$ & $1^{\text {st }} \mathrm{hr}$ & $2^{\text {nd }} \mathrm{hr}$ & $3^{\text {rd }} \mathrm{hr}$ & $4^{\text {th }} \mathrm{hr}$ & $\begin{array}{l}\% \text { diarrhoea } \\
\text { inhibition }\end{array}$ \\
\hline$C D E$ & 100 & $3.8 \pm 0.86$ & $3.4 \pm 0.40$ & $1.4 \pm 0.50^{*}$ & $1.4 \pm 0.50^{*}$ & 5.66 \\
\hline$C D E$ & 200 & $2.0 \pm 0.89$ & $3.4 \pm 0.60$ & $1.8 \pm 0.58^{*}$ & $0.8 \pm 0.20^{*}$ & 24.53 \\
\hline$C D E$ & 400 & $1.8 \pm 0.37^{\star}$ & $2.0 \pm 0.31^{*}$ & $0.0 \pm 0.00^{*}$ & $1.2 \pm 0.37^{\star}$ & 52.83 \\
\hline Loperamide & 2.5 & $1.0 \pm 0.63^{\star}$ & $0.8 \pm 0.80^{*}$ & $0.2 \pm 0.20^{*}$ & $0.0 \pm 0.00^{*}$ & 81.13 \\
\hline Distilled water & $5 \mathrm{~mL} / \mathrm{kg}$ & $2.6 \pm 0.24$ & $2.8 \pm 0.58^{*}$ & $2.8 \pm 0.73$ & $2.4 \pm 0.50$ & 0 \\
\hline
\end{tabular}

$\mathrm{CDE}=$ Caralluma dalzielii extract; values are presented as mean $\pm \operatorname{SEM}(n=5) ;{ }^{*} p<0.05$

Significant when compared to distilled water control group.

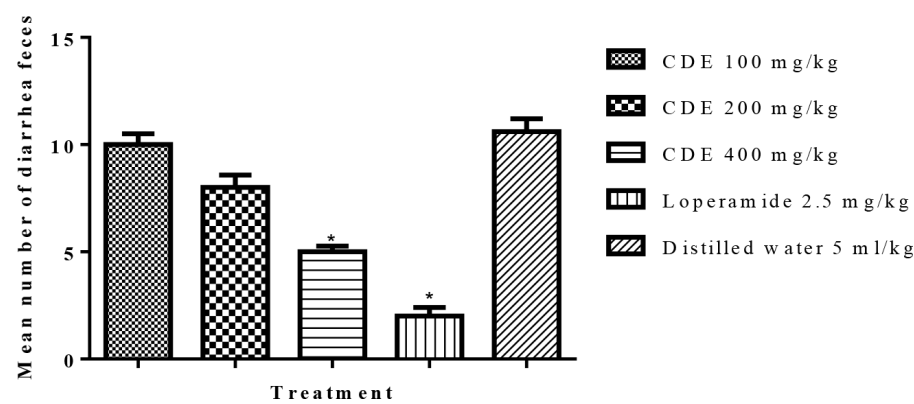

Figure 3: Effect of aqueous extract of Caralluma dalzielii on mean number of feces in castor oil-induced diarrhoea in rats.

Table 3: Effect of aqueous extract of Caralluma dalzielii on PGE2-induced enteropooling in rats.

\begin{tabular}{cccc}
\hline Treatment & $\begin{array}{c}\text { Dose } \\
(\mathrm{mg} / \mathrm{kg})\end{array}$ & $\begin{array}{c}\text { Volume of } \\
\text { intestinal content }\end{array}$ & $\begin{array}{c}\text { \% inhibition of } \\
\text { intestinal fluid }\end{array}$ \\
\hline$C D E$ & 100 & $3.14 \pm 0.37$ & 3.09 \\
$C D E$ & 200 & $3.70 \pm 0.27$ & -14.2 \\
$C D E$ & 400 & $4.87 \pm 0.57^{*}$ & -50.31 \\
Loperamide & 2.5 & $2.68 \pm 0.31$ & 17.28 \\
Distilled water & $5 \mathrm{~mL} / \mathrm{kg}$ & $3.24 \pm 0.27$ & 0 \\
\hline
\end{tabular}

$\mathrm{CDE}=$ Caralluma dalzielii extract; values are presented as mean \pm SEM $(\mathrm{n}=5)$; ${ }^{*} p<0.05$

Significant when compared to distilled water control group.

\section{DISCUSSION}

The study evaluated the antioxidant, antidiarrheal and antispasmodic activities of CDE using different experimental models in Wistar rats. The antioxidant activities were evaluated by determining the TPC, the DPPH scavenging activity and the FRAP of the plant. The antidiarrheal activity was tested against gastrointestinal motility, castor oil-induced and prostaglandin- $\mathrm{E}_{2}$ (PGE2) enteropooling models in Wistar rats. Isolated rabbit jejunum was used to investigate the antispasmodic activity of the extract. The data obtained showed that the extract possessed antioxidant, antidiarrheal and antispasmodic activities.

Free radicals are regarded as one of the major pre-disposing factors in the development of diseases including diarrhoea. ${ }^{[22]}$ Plant polyphenols being the potential source of natural antioxidants have played important role in alleviating such diseases. The presence of phenolic hydroxyl groups in these compounds, confers the antioxidant activity. ${ }^{[23]}$ The

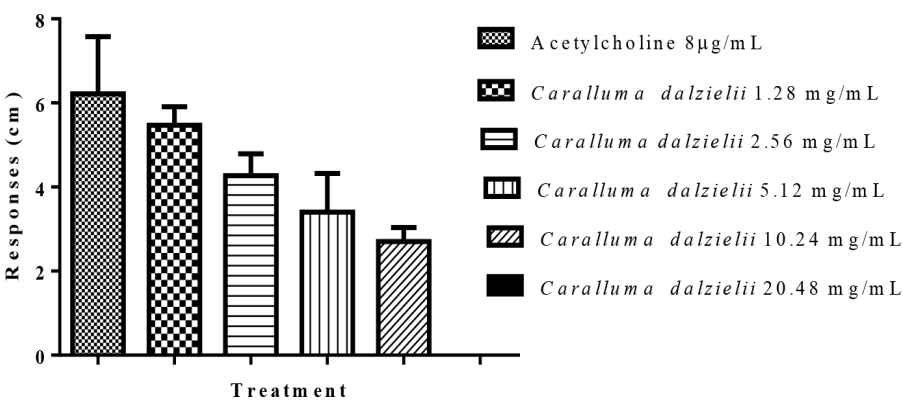

Figure 4: The inhibitory effect of the extract of Caralluma dalzielii on acetylcholine contraction of rabbit jejunum.

phenolic compounds scavenge free radicals by releasing hydrogen atoms and electrons to exhibit their antioxidant capacity. ${ }^{[24]}$ Increase in phenolic content an extract leads to a corresponding increase in its antioxidant activity. ${ }^{[25]}$ Furthermore, water being polar solvent, has the capacity to extract the phenolic compounds. ${ }^{[26]}$ The total phenolic content found in our extract was comparable to previous reports of other plants with antioxidant properties. ${ }^{[27,28]}$ Therefore, the antioxidant activity demonstrated by the aqueous extract of Caralluma dalzielii may be attributed to its phenolic content.

To further ascertain the antioxidant (FRSA) activity of the plant, the DPPH assay was determined. The DPPH assay is regarded as an indication of the capacity of plant extract to scavenge DPPH free radicals by converting unpaired electrons to paired ones. ${ }^{[29]} \mathrm{The} \mathrm{IC}_{50}$ of the extract was lower than that of ascorbic acid showing that the extract possesses a stronger in vitro antioxidant activity. To assess the extract's reducing power, FRAP assay was determined. FRAP assay assesses the reducing ability of a substance (an antioxidant) reacting with ferric tripyridyltriazine complex to produce ferrous tripyridyltriazine which is coloured. ${ }^{[30]}$ Our extract increased the FRAP in a concentrationdependent manner. This property suggests that the extract of Caralluma dalzielii may act as a free radical scavenger that can transform reactive free radical species into stable non-radical products.

In the management of diarrhoea, antimotility and antisecretory agents are regarded as the major agents used to alleviate the pathophysiologic conditions responsible for diarrhoea development. ${ }^{[31]}$ Drugs which are capable of relaxing intestinal smooth muscle are usually employed as antidiarrheal agents. This is because they inhibit the intestinal hyper motility evident in diarrhea disease. ${ }^{[32]}$ In the antidiarrheal study, pretreatment with the extract of Caralluma dalzielii caused a reduction in the gastrointestinal motility suggesting that the extract possesses an antidiarrheal activity. To further verify the antidiarrheal activity of the plant, its effect on castor oil-induced diarrhea was investigated. 
Castor oil induces diarrhea owing to its active metabolite known as ricinoleic acid. ${ }^{[33]}$ Ricinoleic acid stimulates peristaltic activity in the small intestines and cause changes in the permeability of intestinal mucosa to electrolytes. This mechanism cause diarrhea and also leads to the secretion of endogenous prostaglandin. ${ }^{[34]}$ Our extract dose dependently inhibited the mean number of feces produced by the animals. However, the inhibition produced by the standard drug, loperamide, was more than that produced by the extract. Castor oil-induced diarrhea have been shown in previous studies to be inhibited by many plant extracts such as Crataegus azarolus, ${ }^{[35]}$ Bixa orellana, ${ }^{[36]}$ Vitex doniana, ${ }^{[37]}$ and Entada africana. ${ }^{[38]}$

In an attempt to suggest other possible mechanism of activity of the plant extract, the $\mathrm{PE}_{2}$ enteropooling test was carried out. PGE2 produces diarrhoea by inhibiting glucose absorption and causing accumulation of fluid in the intestinal lumen. ${ }^{[39]}$ This implies that drugs with potential inhibitory activity against prostaglandins could be suitable for preventing the enteropooling effect of PGE2. Our extract, however failed to inhibit the hypersecretion and enteropooling in the gastrointestinal tract causing a dose dependent increase in the accumulation of intestinal fluids. This suggests that the extract may not be acting in a similar manner as loperamide whose antidiarrheal mechanism includes inhibiting enteropooling caused by PGE2 ${ }^{[40]}$ The antidiarrheal activity of the extract may therefore be due to its antimotility activity but not antisecretory effect. To confirm its antimotility activity, the antispasmodic activity was carried out using rabbit jejunum.

The extract concentration-dependently inhibited the acetylcholineinduced contractions of the isolated rabbit jejunum. Acetylcholine is an agonist that cause intestinal smooth muscle contraction by activating the muscarinic $\mathrm{M}_{3}$ receptors. ${ }^{[41]}$ It induces smooth muscle contraction via inositol phosphate (IP3) pathway, which mediates $\mathrm{Ca}^{2+}$ release from sarcoplasmic reticulum. ${ }^{[42]}$ The extract from the aerial parts of Caralluma dalzielii possesses antispasmodic activity involving cholinergic mechanism.

Phytochemical constituents of the extract were determined to identify the possible constituents that could be responsible for the antioxidant, antidiarrheal and antispasmodic activities seen with the plant extract. The presence of saponins, terpenoids, alkaloids, tannins and flavonoids detected in the plant extract could be responsible for these activities. In a similar experiment, the antidiarrheal activities of some medicinal plants were found to be due to the presence of tannins, alkaloids, saponins and flavonoids contained in them. ${ }^{[43]}$

\section{CONCLUSION}

The present study showed that CDE possesses antidiarrheal, antioxidant and spasmolytic activities. The results obtained also showed that the antidiarrheal properties of CDE may be due to its antioxidant and spasmolytic properties. This study thus provides the pharmacological evidence for its use in the traditional setting for treating gastrointestinal disorders. Further studies are required to isolate and characterize active compounds in the plant.

\section{ACKNOWLEDGEMENT}

The authors are grateful to Mallam Dahiru of the Department of Biochemistry for assisting with the antioxidant studies.

\section{CONFLICT OF INTEREST}

The authors declare no conflict of interest.

\section{ABBREVIATIONS}

ACh: acetylcholine; CDE: extract of Caralluma dalzielii; DPPH: 1, 1-Diphenyl-2-Picrylhydrazyl; FRAP: ferric reducing antioxidant power;
FRSA: free radical scavenging activity; GIT: gastrointestinal tract; PGE2: prostaglandin- $\mathrm{E}_{2}$; TLI: total length of the intestine; TPC: total phenolic content.

\section{SUMMARY}

The antidiarrheal and antioxidant activities of the aqueous extract of the aerial parts of Caralluma dalzielii N. E. Brown were studied by determining its effect on gastrointestinal motility, castor oil-induced and PGE2 enteropooling models in Wistar rats. The antioxidant parameters, TPC, FRSA using DPPH and FRAP assays were determined. Spasmolytic property was studied in isolated rabbit jejunum preparations. The extract reduced gastrointestinal transit of charcoal meal and the total number of diarrheal feces in the animals. The TPC was $36.67 \pm 3.33 \mathrm{mg} \mathrm{GAE} / \mathrm{g}$. $\mathrm{IC}_{50}$ of extract was $63.44 \mathrm{mg} / \mathrm{mL}$ while that of ascorbic acid was $80.47 \mathrm{mg} / \mathrm{mL}$ in DPPH assay. The FRAP value increased in a concentration dependent manner. The extract inhibited acetylcholine-induced contraction of the rabbit jejunum with complete inhibition at $20.48 \mathrm{mg} / \mathrm{mL}$ of the extract. The extract of Caralluma dalzielii possesses antidiarrheal activities which may be related to its antimotility, antioxidant and antispasmodic properties.

\section{REFERENCES}

1. World Health Organization. Key facts Scope of diarrheal disease. World Heal (Organ). 2017

2. Reintam Blaser AR, Deane AM, Fruhwald S. Diarrhoea in the critically ill. Curr Opin Crit Care. 2015:21(2):142-53. doi: 10.1097/MCC.0000000000000188, PMID 25692805.

3. Jo $\mathrm{E}$, Jang $\mathrm{HJ}$, Yang $\mathrm{KE}$, Jang MS, Huh $\mathrm{YH}$, Yoo HS, et al. Cordyceps militaris induces apoptosis in ovarian cancer cells through TNF- $\alpha /$ TNFR1-mediated inhibition of NF-kB phosphorylation. BMC Complement Med Ther. 2020;20(1):1. doi: 10.1186/s12906-019-2780-5, PMID 32020859

4. Banwo K, Alao MB, Sanni Al. Antioxidant and antidiarrhoeal activities of methanolic extracts of stem bark of Parkia biglobosa and leaves of Parquetina nigrescens. J Herbs Spices Med Plants. 2020;26(1):14-29. doi: 10.1080/10496475.2019.1663770.

5. Aragaw TJ, Afework DT, Getahun KA. Assessment of knowledge, attitude, and utilization of traditional medicine among the communities of Debre Tabor Town, Amhara Regional State, North Central Ethiopia: A cross-sectional study. Evid Based Complement Alternat Med. 2020;2020:6565131. doi: 10.1155/2020/6565131.

6. Mohammadi S, Jafari B, Asgharian P, Martorell M, Sharifi-Rad J. Medicinal plants used in the treatment of Malaria: A key emphasis to Artemisia, Cinchona, Cryptolepis, and Tabebuia genera. Phytother Res. 2020 Jul;34(7):1556-69. doi: 10.1002/ptr.6628, PMID 32022345.

7. Salimon SS, Yakubu MT. Antidiarrhoeal activity of fractions of aqueous extract of Mangifera indica $L$. leaves in castor oil-induced diarrhoeal female Wistar rats. JOMPED. 2020;4(1):1-7. doi: 10.4102/jomped.v4i1.88.

8. Ahmad MH, Zezi AU, Anafi SB, Alhassan Z, Mohammed M, Danraka RN. Mechanisms of antidiarrhoeal activity of methanol leaf extract of Combretum hypopilinum diels (Combretaceae): Involvement of opioidergic and ( $\alpha 1$ and $\beta$ )-adrenergic pathways. J Ethnopharmacol. 2021;269:113750. doi: 10.1016/j. jep.2020.113750.

9. Shukla D, Gahlot K. Evaluation of antidiarrhoeal activity of the leaves and stem of Bauhinia vahlii. Pharmacogn J. 2020;12(6):1389-94. doi: 10.5530/ pj.2020.12.192.

10. Akter A, Begh MZ, Islam F, AfrozT, Hossain MS, Faysal M, et al. Phytochemical screening and evaluation of thrombolytic, analgesic and antidiarrhoeal activity of the leaves of Cucumis sativus linn.(Cucurbitaceae) of methanolic extracts. J Pharm Sci Res. 2020;12(3):448-51.

11. Ugwah-Oguejiofor CJ, Okoli CO, Ugwah MO, Umaru ML, Ogbulie CS, Mshelia HE, et al. Acute and sub-acute toxicity of aqueous extract of aerial parts of Caralluma dalzielii N.E. Brown in mice and rats. Heliyon. 2019;5(1):e01179. doi: 10.1016/j. heliyon.2019.e01179, PMID 30775575.

12. Dalziel JM. The useful plants of West Tropical Africa, crown Agent for the colonies. Vol. 1. Millbank: Westminster Publications. SW: London; 1937;612.

13. Ugwah-Oguejiofor CJ, Abubakar K, Ugwah MO, Njan AA. Evaluation of the antinociceptive and anti-inflammatory effect of Caralluma dalzielii. I Ethnopharmacol. 2013;150(3):967-72. doi: 10.1016/j.jep.2013.09.049, PMID 24140204.

14. Trease GE, Evans WC. Pharmacognosy. London: Bailliere Tindall Press: $1983 ; 309-706$ 
15. Gámez-Meza N, Noriega-Rodríguez JA, Medina-Juárez LA, Ortega-García J, Cázarez-Casanova R, Angulo-Guerrero O. Antioxidant activity in soybean oil of extracts from Thompson grape bagasse. J Am Oil Chem Soc. 1999;76(12):1445. doi: 10.1007/s11746-999-0182-4.

16. Jain A, Soni M, Deb L, Jain A, Rout SP, Gupta VB, et al. Antioxidant and hepatoprotective activity of ethanolic and aqueous extracts of Momordica dioica Roxb. leaves. J Ethnopharmacol. 2008;115(1):61-6. doi: 10.1016/j. jep.2007.09.009, PMID 17983713.

17. Oyaizu M. Studies on products of browning reaction. Antioxidative activities of products of browning reaction prepared from glucosamine. Jpn J Nutr Diet. 1986;44(6):307-15. doi: 10.5264/eiyogakuzashi.44.307.

18. Ugwah OM, Ugwah-Oguejiofor CJ, Abubakar K, Okorie NA, Njan AA. Antidiarrhoeal activities of aqueous stem bark extract of Amblygonocarpus andongensis (Welw. ex Oliv.) Exell and Torre. Nig J Pharm Sci. 2014;13(2):1-

19. Chitme HR, Chandra M, Kaushik S. Studies on anti-diarrhoeal activity of Calotropis gigantea R.Br. in experimental animals. J Pharm Pharm Sci. 2004;7(1):70-5. PMID 15144737.

20. Robert A, Nezamis JE, Lancaster C, Hanchar AJ, Klepper MS. Enteropooling assay: A test for diarrhea produced by prostaglandins. Prostaglandins. 1976;11(5):809-28. doi: 10.1016/0090-6980(76)90189-1, PMID 935512.

21. Cortés AR, Delgadillo AJ, Hurtado M, Domínguez-Ramírez AM, Medina JR, Aoki K. The antispasmodic activity of Buddleja scordioides and Buddleja perfoliata on isolated intestinal preparations. Biol Pharm Bull. 2006;29(6):1186-90. doi: 10.1248/bpb.29.1186, PMID 16755014

22. Noreen H, Semmar N, Farman M, McCullagh JSO. Measurement of total phenolic content and antioxidant activity of aerial parts of medicinal plant Coronopus didymus. Asian Pac J Trop Med. 2017;10(8):792-801. doi: 10.1016/j. apjtm.2017.07.024, PMID 28942828.

23. Mshelia EH, Mathias SN, Umaru MM, Adam AB. Phytochemical and antioxidant evaluation of Cassia sieberiana DC stem bark extracts. Proceedings of the Nigerian acad sci. 2021;13(2):97-110.

24. Devi SG, Dhamotharan R. Preliminary studies on phytochemical screening and in vitro antioxidant activities of Caralluma fimbriata. World J Pharm Res. 2016 Jan 25;5(4):1097-107.

25. De la Rosa LA, Moreno-Escamilla JO, Rodrigo-García J, Alvarez-Parrilla E. Phenolic compounds. In: Yahia EM, editor. Postharvest physiology and biochemistry of fruits and vegetables. Cambridge, UK: Woodhead Publishing 2019;253-71.

26. Adaramola B, Onigbinde A. Effect of extraction solvent on the phenolic content, flavonoid content and antioxidant capacity of clove bud. IOSR JPBS. 2016:11(3):33-8.

27. Halilu EM, Abdurrahman AM, Mathias SN, Ugwah-Oguejiofor CJ, Abdulrahman M, Abubakar S. Phytochemical and antioxidant activity of Cadaba farinosa Forssk stem bark extracts. Phys Sci Rev. 2021;2021. doi: 10.1515/psr-2020-0088, PMID 20200088

28. Bristy TA, Barua N, Montakim Tareq A, Sakib SA, Etu ST, Chowdhury KH, et al. Deciphering the Pharmacological Properties of methanol Extract of Psychotria calocarpa Leaves by in vivo, in vitro and in silico Approaches. Pharmaceuticals (Basel). 2020;13(8). doi: 10.3390/ph13080183, PMID 32781707.

29. Derakhshan Z, Ferrante M, Tadi M, Ansari F, Heydari A, Hosseini MS, et al. Antioxidant activity and total phenolic content of ethanolic extract of pomegranate peels, juice and seeds. Food Chem Toxicol. 2018;114:108-11. doi: 10.1016/j.fct.2018.02.023, PMID 29448088.

30. Karthishwaran K, Shamisi SOSOA, Kurup SS, Sakkir S, Cheruth AJ. Free-radicalscavenging and antioxidant capacities with special emphasis on enzyme activities and in vitro studies in Caralluma flava N. E. Br. Biotechnol Biotechno Equip. 2018;32(1):156-62. doi: 10.1080/13102818.2017.1379362.

31. Mekonnen B, Asrie AB, Wubneh ZB. Antidiarrheal activity of $80 \%$ methanolic leaf extract of Justicia schimperiana. Evid Based Complement Alternat Med. 2018;2018:3037120. doi: 10.1155/2018/3037120.

32. Onoja SO, Ihejirika GQ, Nwankudu ON, Omeh YN, Ezeja MI. Antidiarrheal and antioxidant activities of methanol extract of Bryophyllum pinnatumleaf harvested from south-eastern Nigeria in mice. J Pharm (Cairo). 2018;2018:6810620. doi: 10.1155/2018/6810620, PMID 30002943

33. Musa AM, Sule MI, Haruna AK, Ilyas M, Iliya I, Yaro AH, et al. Preliminary gastrointestinal studies of methanol extract of Indigofera pulchra willd in rodents. Niger J Pharm Sci. 2008 Mar;7(1):86-92. PMID 21197141.

34. Dosso K, N'guessan BB, Bidie AP, Gnangoran BN, Méité S, N'guessan D, et al. Antidiarrhoeal activity of an ethanol extract of the stem bark of Piliostigma reticulatum (Caesalpiniaceae) in rats. Afr $\mathrm{J}$ Tradit Complement Altern Med. 2012;9(2):242-9. doi: 10.4314/ajtcam.v9i2.9, PMID 23983341.

35. Sammari $\mathrm{H}$, Jedidi $\mathrm{S}$, Selmi H, Rtibi K, Jabri MA, Jridi M, et al. Protective effects of Crataegus azarolus L. berries aqueous extract against castor oil-induced diarrhea, oxidative stress, and inflammation in rat. Neurogastroenterol Motil. 2021;33(6):e14065. doi: 10.1111/nmo.14065, PMID 33320393

36. Fokam Tagne MA, Akaou H, Noubissi PA, Foyet Fondjo A, Rékabi Y, Wambe $\mathrm{H}$, et al. Effect of the hydroethanolic extract of Bixa orellana Linn (Bixaceae) Leaves on castor oil-induced diarrhea in Swiss albino mice. Gastroenterol Res Pract. 2019;2019:6963548. doi: 10.1155/2019/6963548, PMID 31885545.

37. Amuzat A, Ndatsu Y, Adisa M, Sulaiman R, Mohammed H, Yusuf A, et al. Antidiarrhoeal Effects of Aqueous Extract of Vitex doniana Stem Bark in castor oil-induced Wistar rats. Tanzan J Sci. 2020 Oct 30;46(3):723-32.

38. Mu'azu AB, Usman Ml. Effect of aqueous ethanol stem extract of Entada africana Guill. et Perrott. on Castor Oil and Magnesium Sulphate-induced Diarrhoea Models in Mice. Asian J Res Pharm Sci. 2020;30:1-9.

39. Ayele TM, Abebe EC, Kassie AB. Investigation of Antibacterial and AntiDiarrhoeal Activities of $80 \%$ Methanol Leaf and Fruit Extract of Leonotis ocymifolia (Burm. F) Iwarsson (Lamiaceae). J Exp Pharmacol. 2021;13:613-26.

40. Suleiman MM, Oyelowo BB, Abubakar A, Mamman M, Bello KT. A controlled study to investigate anti-diarrhoeal effect of the stem-bark fractions of Terminalia avicennioides in laboratory animal models. Int J Vet Sci Med. 2017;5(1):14-22 doi: 10.1016/j.ijvsm.2017.04.002, PMID 30255043.

41. LiY, Li J, Liu X, Zhang J, Mei X, Zheng R, et al. Antidiarrheal activity of methanol extract of Sophora tonkinensis in mice and spasmolytic effect on smooth muscle contraction of isolated jejunum in rabbits. Pharm Biol. 2019;57(1):477-84 doi: 10.1080/13880209.2019.1645701, PMID 31438784.

42. Bolton TB. Mechanisms of action of transmitters and other substances on smooth muscle. Physiol Rev. 1979;59(3):606-718. doi: 10.1152/ physrev.1979.59.3.606, PMID 37533.

43. Kubacey TM, Haggag EG, El-Toumy SA, Ahmed AA, El-Ashmawy IM Youns MM. Biological activity and flavonoids from Centaurea alexandrina leaf extract. J Pharm Res. 2012;5(6):3352-61.

\section{GRAPHICAL ABSTRACT}

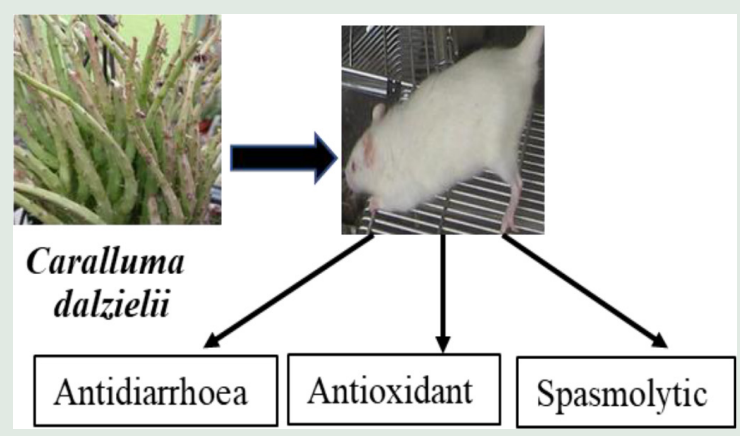

\section{SUMMARY}

The antidiarrheal and antioxidant activities of the aqueous extract of the aerial parts of Caralluma dalzielii N. E. Brown were studied by determining its effect on gastrointestinal motility, castor oil-induced and PGE2 enteropooling models in Wistar rats. The antioxidant parameters, TPC, FRSA using DPPH and FRAP assays were determined. Spasmolytic property was studied in isolated rabbit jejunum preparations. The extract reduced gastrointestinal transit of charcoal meal and the total number of diarrheal feces in the animals. The TPC was $36.67 \pm 3.33 \mathrm{mg} \mathrm{GAE} / \mathrm{g}$. $\mathrm{IC}_{50}$ of extract was $63.44 \mathrm{mg} / \mathrm{mL}$ while that of ascorbic acid was $80.47 \mathrm{mg} / \mathrm{mL}$ in DPPH assay. The FRAP value increased in a concentration dependent manner. The extract inhibited acetylcholine-induced contraction of the rabbit jejunum with complete inhibition at $20.48 \mathrm{mg} / \mathrm{mL}$ of the extract. The extract of Caralluma dalzielii possesses antidiarrheal activities which may be related to its antimotility, antioxidant and antispasmodic properties. 


\section{ABOUT AUTHORS}

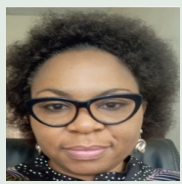

Dr. Chinenye Ugwah-Oguejiofor is a Senior Lecturer at the Department of Pharmacology and Toxicology, Usmanu Danfodiyo University, Sokoto State, Nigeria.

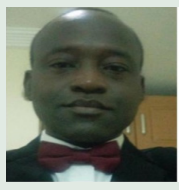

Dr. Halilu Mshelia is an Associate Professor at the Department of Pharmacognosy and Ethnopharmacy, Usmanu Danfodiyo University, Sokoto, Nigeria. He is currently working at the Department of Pharmacy, Cyprus International University, Nicosia, Mersin 10, Turkey.

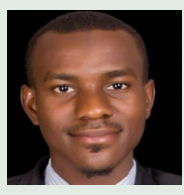

Junaidu Bello is a graduate of Pharmacy from the Department of Pharmacology and Toxicology, Usmanu Danfodiyo University, Sokoto.

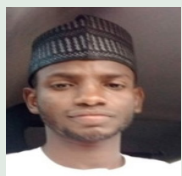

Isah Inuwa is a graduate of Pharmacy from the Department of Pharmacology and Toxicology, Usmanu Danfodiyo University, Sokoto.

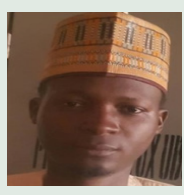

Mr. Abdullahi Sulaiman is a Senior Laboratory Technologist from the Department of Pharmacology and Toxicology, Usmanu Danfodiyo University, Sokoto.

Cite this article: Ugwah-Oguejiofor C, Mshelia, Junaidu, Isah, Abdullahi. Antidiarrheal and Antioxidant Activities of the Aerial Parts of Caralluma dalzielii N. E. Brown. Pharmacog Res. 2022;14(1):82-8. 